\title{
The Local Knowledge of Dayaknese: Case Study of Pahewan Tabalien
}

\author{
Merrisa Octora \\ Sociology Department \\ Universitas Palangkaraya \\ Palangka Raya, Indonesia \\ mcoctora@gmail.com
}

\begin{abstract}
Central Kalimantan is widely known for its great potential for natural resources scattered throughout the regencies. In addition, the original belief of Central Kalimantanese derived from the value of Dayaknese was namely Kaharingan that is well known with the term of "Agama Helu" which has a great connection with human and nature. Most of the area of Central Kalimantan is still covered with thick forest and cultivation areas of local people until the early of 1990. Nevertheless, the development changes the landscape rapidly with the significant growth of economic and the spreading of palm oil plantation, logging company and mining sector since 1993. Directly it causes major impacts toward the society and environment either positive or the negative. However, the tradition and belief still embedded in the Dayaknese by implementing the traditional rule and local knowledge toward this massive change. In this paper, the author focuses on one of the local knowledge called Pahewan.
\end{abstract}

Keywords- Pahewan, Dayaknese, Highly Value of Conservation Area, Sustainable Livelihood

\section{INTRODUCTION}

The Dayaknese old saying above has moral value toward the society in the relationship between God, People, and Environment. How the Dayaknese appreciates the nature and applies the local wisdom thought toward the environment wisely. The connection between human and environment for Dayaknese in Central Kalimantan can be reflected in the word of cosmos. The harmonious life of human and nature. The natural environment has the fundamental position between God and People Environment and ecosystem become the biggest essential part of life for Dayaknese in Central Kalimantan.

The life of Dayaknese cannot be separated from nature, like the cycle of takes and gives. Nature gives abundantly resources to the society and the society cultivated and maintained the natural resources for the good deed for nature and human being. Those aspects cannot be separated from the local knowledge.

According to FAO of The United Nations in What Is Local Knowledge "Local knowledge is the knowledge that people in a given community have developed over time and continue to develop. It is based on the experience, often tested over centuries of use, adapted to the local culture and environment, embedded in community practices, institution, relationships and rituals, held individuals and communities, dynamic and changing. It is clearly stated that local knowledge is an essential part of the society as seen in the life of Dayaknese in Central Kalimantan which reflects in the concept of Batang Garing.

\section{RESEARCH METHOD}

The research problems of this writing are how local people especially Dayaknese can maintain and preserve their life through traditional values and accepting the modernization by the existence of the company without disturbing the holy forest. The method of this research is using the qualitative method to describe the situation from the problem arises within the society and applying the descriptive method in analyzing the data through field observation and interview on Agustus 2017. This approaches which are used have a great related with the society, especially for the Dayaknese. This approaches well known with the term of interdisciplinary study which has the main purpose to elaborate many perspectives to become the primary source. Data to be used in this study were data obtained from relevant government agencies such as environmental agencies, forestry services, government regulations, reports from nongovernmental organizations.

\section{LITERATURE REVIEW}

Kalimantan Tengah has various of local knowledge system in which embedded in the society as a way of life. The definition of Local Knowledge can be defined as the way of life for certain people. According to FAO local knowledge is the knowledge of the people in a given community have developed over time and continue to develop, it is [1]:

a. Based on experience

b. Often tested over centuries of use

c. Adapted to the local culture and environment

d. Embedded in community practices, institutions, relationships and rituals.

e. Held by individual and community.

f. Dynamic and changing

The local knowledge also can be related with the term of Indigenous knowledge. According to CCIAM (Climate Change Impacts, Adaption, and Mitigation Program in Tanzania Indigenous Knowledge is considered as one of the greatest assets of a community in a time when the climate is changing this knowledge can help them to adapt to these changes and control in the environment around them. According to the Environmental Management Agency, Indigenous Knowledge is [2]: 
1. Local: It is rooted in a particular set of experiences, and generated by people living in those places. It has been said that transferring that knowledge to other places runs the risk of dislocating it.

2. Orally- transmitted, or transmitted through imitation and demonstration. Writing it down changes some of its fundamental properties.

3. The consequence of practical engagement in everyday life, and is constantly reinforced by experience and trial and error. This experience is characteristically the product of many generations of intelligent reasoning, and since its failure has the immediate consequence for the lives of its practitioners its success is very often a good measure of Darwinian fitness.

4. Characteristically shared to a much greater degree than other forms of knowledge, including global science. This is why it is sometimes called "people's science", an appellation which also arises from its generation in contexts of everyday production. It is usually asymmetrically distributed within a population, by gender and age, for example, and preserved through distribution in the memories of the different individual. Specialists may exist by virtue of experience, but also by virtue of ritual or political authority.

5. Focused on particular individuals and may achieve a degree of coherence in rituals and other symbolic constructs, its distribution is always fragmentary: it does not exist in this totality or individual, Indeed, to considerable extent it is devolved not in individuals at all, but in the practices and interactions in which people engage themselves engage.

Based on the literature review it can be concluded that Pahewan (Forbidden Forest/Area) in which considered as restricted area for people activities can be categorized into Local Knowledge system of the Dayaknese society because it contains several aspects such as it embedded for many centuries among communities, based on experience from the old ancestors mostly in orally system, the purpose is to preserve the natural resources and it relates with the sustainable development in term of local knowledge and can be concluded as the people' sciences.Maintaining the Integrity of the Specifications

\section{RESEARCH RESULT}

Pahewan is considered as a forbidden place, which is restricted to the general activity because this place is considered as a holy place. In Kalimantan Tengah there are so many places which are considered as a holy and forbidden place but based on the latest research there are still three pahewan remained and the others pahewan still ongoing process to be identified because according to the local people every part of the areas in Kalimantan Tengah there will be a place which is considered as a forbidden place or forest.

According to Usop One indicator of pahewan (forbidden) by Dayak people is known as the Keramat forest consisting of banyan tree, patahu (ancestral spirits) and yellow flag as a marker [3]. Furthermore, in the study explained that in
Central Kalimantan there are some forest areas that are sacred (Pahewan) by the community, among others:

1. Pahewan Klaru: Pahewan Tumbang Klaru is a square of sand and lake lake lake known by local people as Klaru lake. The forest area is Pahewan Klaru which is located in Klaru river of Katingan Regency.

2. Pahewan Forest of Kalawa: Forest has $7000 \mathrm{Ha}$ on the east bordering PT. Kahayan Timber is adjacent to the former peatland development in the west, south side bordered by Buntui village and the north by Garung village.

3. Pahewan tabalien Forest: The Tabalien Forest area is less than 16,000 ha, which is closely related to the Bawi Kuwu cultural site of Sandung and Pantar, so the sacred value of the area is very strong in the formation of community knowledge. The area of the forest is dominated by trees Tabalien / Ulin / Wood Iron. Based on the description above, then between forest and humans have caused interdependence since the beginning of civilization because the forest is able to provide basic materials needed for human life such as food, clean air, and protection. Taking into account the very importance of the relationship between humans and the environment then the areas considered sacred by Dayak customary communities have been made customary rules such as that done by the Dayak Customary Council of Kapuas Regency by compiling the Dayak Ngaju Traditional Law which in article 85 on the rules of Damang

Pahewan tabalien in Rakumpit area of Mungku Baru subdistrict has the main vegetation is ulin with very old age with the diameter of tree circle which is wide enough and is in the area with very dense cover (canopy) with wide range of cruising area by passing the path made by local people through the bushes, some bridges from fallen trees, or rivers due to inadequate facilities and bridges

The main focus of this research is on Pahewan tabalien because this Pahewan has specific characteristic by having homogenous vegetation of ironwood or in local term people call it Kayu Ulin. According to Ranan one form of local wisdom in the practice of shifting [4]. This writing focuses on how local people react especially for the Dayaknese in maintaining traditional and accepting the modernization values through Pahewan tabalien, which is considered as a holy place related with sustainable livelihood perspectives and supported by other local knowledge. Cultural and environment preservation also the growth of economic will bring many changes in many aspects of the society and can be explicated as two sides of the same coin. Both preservation and development look closely the same but actually incompatible. However, those problems need to be solved by maintaining cultural aspects together with sustainable development aspects. The Dayaknese have many local pieces of knowledge about the environment such as how they cultivated the field based on the position.

Dayak tribe in Central Kalimantan, in particular, recognize 4 (four) types of areas that can be used as a location for farming, such as :

1. Pukung Himba. This area can be classified as primary forest, is a virgin forest that has not been 
touched by humans overgrown with large trees older than 20 years with a little shrub underneath. This type of forest is hardly found in the practice of shifting cultivation, as the depletion of the primary forest area and in general, is very far from residential areas and difficult to reach by the cultivators.

2. Bahu Baliang. Baliang shoulder is a type of secondary forest which is a former area of cultivation that is overgrown with forest types with a fallow period of over 10 years and overgrown with trees of considerable size for nesting birds so that the type of forest by the Dayak Ngaju community is called baliang shoulder. In addition, the trees can only be felled when using ax baling or pickaxe and have thick enough thickets. In this type of land sometimes still encountered plants such as rubber, durian tree, mango species kuini, tamarind, and some other types of fruit crops. The existence of these plants is usually used as a sign of ownership of this land by the citizens and their status is recognized, both customarily and by the local community.

3. Bahu Lakau. Bahu Lakau is a grove of trees with young trees the size of an adult's foot (about 15-20 $\mathrm{cm})$. This land is a former field left by the farmers and eaten between 4 - 10 years. This location is sometimes still found a former hut surrounding the overgrown various types of annual crops and fruits.

4. Bahu Tampilai. Bahu Tampilai is a cultivated area that is overgrown with grassland and grass, which is a former field that is eaten between 1-3 years and when there is a large tree grown just about the size of an adult's hand (about 5-10 cm). At this location wring found certain plants such as bananas, climbing, eggplant acid (rimbang) and several other vegetables. This type of land is currently widely cultivated community in Pulang Pisau District as a farming location.

As described above one of the customary forests wherein maintaining the balance between human beings and their environment, it is claimed by Dayak indigenous peoples that there is a forest area considered sacred and forbidden (Pahewan) which is believed that the area is awaited or guarded by supernatural spirits as the guardian of the area and if we enter the area there are taboos that must be guarded which if violated will be dangerous for anyone who violates the ban and this has been understood by the people residing in the area of indigenous peoples and become consensus together in society. Based on the description above the local knowledge system in Dayaknese can be found as the alternative system of farming because it has been applied throughout many years from the old ancestor, the belief of the society in appreciate the natural resources also become the main aspects for this system.

Riwut explains that man is said to be good or perfect if he is capable of carrying out all customary law and pali law which is an unwritten ban which should not be done but has been well understood by Dayak people, in case of violation will be very fatal consequences, borne by many parties and nature will punish them [6]. Dayaks are very respectful of their ancestors, such respect is revealed in all their daily attitudes and deeds. Something that is not sanctioned by an ancestor such as abstinence from an incident (amulet), in fact, the Dayaks will not dare to do it, because they are afraid of plagues or qualities. Every Dayak will always try to live or below, which means to observe the customary law and to obey the law of pali, and this tradition is an ancestral heritage that has been formed and integrated into their lives. In view of the Dayak Ngaju community, pali law means a ban to be obeyed. If the prohibition has been disobeyed, then the offense must be neutralized. If left alone, the harmony of nature will be disrupted, the result can be catastrophic and catastrophic for many people even the whole village will be affected. This is believed by Dayak Ngaju people who are in Kalimantan, therefore, the balance of the relationship with nature has deep meaning for the society, because nature is the provider of all needs which must then be respected, maintained and preserved.

Ukur explains that according to the Dayak's response, people who obey all customary law and obey pali (taboo) law are called good human beings [5]. A person who directs all his life and his actions and deeds to obey, fulfill and execute the divine order and strive to perform his duties and functions in the cosmos, he is regarded as the perfect man.

Goodman, perfect man in Ngaju Dayak language is called oloh bahadat (people who have a duty or a person who has adat). A person is judged on the basis of his allegiance of customary law and obeying the law of pali, therefore when a person breaks the custom he is already outside the realm of sacred communion, he has been away from the area of blessing and the highest divinity. The person who violated the customary law and the palient law has left the place that was originally given for him to preserve the harmony and balance of the cosmos (the universe). Such circumstance is equivalent to the person's rejection of the function assigned to him, which is basically for his own sake because of his disobedience it is not only e. he himself who has sentenced him, but also means that the disobedient act also contributes to tension in the balance of the cosmos, resulting in a disturbance in the cosmic order itself. Indigenous and violent violations result in cosmic harmony will be disturbed and cause damage in the balance of the cosmos. Any disturbance and damage to the cosmos must be repaired immediately so that people are kept away from bad circumstances.

In relation to this remedy, there are provisions concerning legal requirements, each according to the severity of an interruption occurring that is equal to the value of the offenses committed. Thus, a perfect man or a good human being will not commit adultery, because he is aware and knows his function and position in maintaining the harmony and balance of the cosmos (the universe).

\section{CONCLUSION}

Based on the field observation through September and August 2017 there are some activities usually held in the area of Pahewan in general. There are several of cultural activities in the area of Pahewan, such as :

1. Manajah Antang (the process of asking direction or clue by the ritual of manawur behas (throwing the rice seeds). 
2. Manyanggar is the process in openeing new area by asking permit from the ancestors' spirit to cultivate outside the area of pahewan (forbidden area).

3. Manyanggiang is the process in collecting the information from the old ancestors about the spirit owner of this pahewan.

4. Bahajat or Membayar Hajat is the process of asking the old ancestors spirit by giving them the offering so that they can fulfill the requests.

\section{REFERENCES}

[1] FAO, Economic and Social Development Department, What Is Local Knowledge, http://www.fao.org/docrep/007/y5610e/y5610e01.html, Accessed date 30 April 2018

[2] Environmental Management Agency, Indigenous Knowledge -are we losing our traditional practices? https://www.ema.co.zw/index.php/129-indigenous-knowledge-are- we-losing-our-traditional-practices.html, Accessed date 29 Maret 2018.

[3] Environmental Management Agency, Indigenous Knowledge -are we losing our traditional practices?, https://www.ema.co.zw/index.php/129-indigenous-knowledge-arewe-losing-our-traditional-practices.html, Accessed date 29 Maret 2018.

[4] S.R Usop, (Social-custom space in the global warming) "Ruang Masyarakat Adat Dalam Pemanasan Global". http://ejournal.lipi.go.id/index.php/index/index, Accessed Date 29 Maret 2018

[5] P.E.Ranan, (The portrait of the filed cultivation in Pulang Pisau Regency) "Potret perladangan di Kabupaten Pulang Pisau". Program Pasca Sarjana Program Study Pengelolaan Sumberdaya Alam dan Lingkungan Universitas Palangka Raya. Palangka Raya, 2008.

[6] F. Ukur, (The religion of Dayak tribe: Hindu Kagaringan, in the review) "Agama Suku Dayak: Hindu Kaharingan, dalam peninjau”. BPK Gunung Mulia. Jakarta, 1991/1993.

[7] T. Riwu, (Developing Kalimantan) "Kalimantan Membangun". Jayakarta Agung Offset. Jakarta, 1979. 